\title{
Correction: neonatal mortality and child health in a remote rural area in Nepal: a mixed methods study
}

Karki BK, Kittel G. Neonatal mortality and child health in a remote rural area in Nepal: a mixed methods study. BMJ Paediatrics Open 2019;3:e000519. doi: 10.1136/ bmjpo-2019-000519

This article was previously published with an error.

Correct Contributors statement is:

Contributors: GK collected the data and has done the interviews, BK and GK did the study design, GK has developed the section on methodology, BK and GK did the analysis of the data and the interpretation of the data, BK and GK developed together the discussion as well as the summary and conclusion. Professor Trevor Duke (TD) served as senior academic adviser.

Correct affiliation for Bindu Kumari Karki is:

Charité - Universitätsmedizin Berlin, corporate member of Freie Universität Berlin, Humboldt-Universität zu Berlin, and Berlin Institute of Health, Institute of Tropical Medicine and International Health

Open access This is an open access article distributed in accordance with the Creative Commons Attribution Non Commercial (CC BY-NC 4.0) license, which permits others to distribute, remix, adapt, build upon this work non-commercially, and license their derivative works on different terms, provided the original work is properly cited, appropriate credit is given, any changes made indicated, and the use is non-commercial. See: http://creativecommons.org/licenses/by-nc/4.0/.

(C) Author(s) (or their employer(s)) 2019. Re-use permitted under CC BY-NC. No commercial re-use. See rights and permissions. Published by BMJ.

BMJ Paediatrics Open 2019;3:e000519corr1. doi:10.1136/bmjpo-2019-000519corr1

A) Check for updates 